IVANA D. NEŠIĆ ${ }^{1}$

BUSINESS SCHOOL OF APPLIED STUdIES

BLACE

KIMETA Ć. HAMIDOVIĆ

STATE UNIVERSITY OF NOVI PAZAR

FACULTY of Philology

DePARTMENT OF PhILOLOGICAL SCIENCES

\title{
TEACHING ENGLISH GRAMMAR: EFFICIENCY OF INDUCTIVE AND DEDUCTIVE APPROACHES - STUDENTS' PERCEPTIONS ${ }^{3}$
}

ABSTRACT. This paper is aimed at investigating students' attitudes towards inductive and deductive approaches to teaching grammar of English as a foreign language. The study includes 134 students of Business School of Applied Studies in Blace. The research was conducted through a questionnaire which consists of 15 items concerning teaching English language, which students rated according to the Likert scale. At the beginning, different approaches to teaching grammar of a foreign language - inductive and deductive are presented. Namely, it has been a constant debate whether grammar rules should be explicitly explained and then practiced through numerous examples, or whether the acquisition of foreign language grammar is more efficient when students are exposed to a foreign language and, based on context and everyday situations, they induce the rules by themselves. According to the results of the questionnaire, over $70 \%$ of the students preferred the deductive approach to teaching English grammar, whereas over $40 \%$ of them acknowledged that the implicit approach is also important for grammar acquisition. Another conclusion indicates that the efficient acquisition of English grammar occurs when these two approaches are combined.

ivana0801@hotmail.com

khamidovic@np.ac.rs

3 This paper was submitted on 12 February 2015 and accepted for publication at the meeting of the Editorial Board held on 8 October 2015. 
KEY WORDS: teaching English grammar, inductive approach, deductive approach, students' preferences

This paper explores acquisition of English language grammar. Grammar, as one of the elements of a language structure, has had various roles in the teaching and learning of foreign languages. During the historical development of the teaching practice, there have been periods when the teaching consisted merely of learning the rules of forming grammatical structures, usually by memorizing and without deeper understanding 4 . For some period the experts on teaching have stated that knowledge of grammar can be a difficulty, even an obstacle, creating some kind of resistance when it comes to learning a foreign language (Thornbury, 1999) 5 . Those experts believed that it was sufficient that students learn a certain number of sentential models, thus acquiring the ability of communicating in a foreign language. This viewpoint was as inappropriate as the excessive insistence on grammar rules. Nowadays, the researchers have agreed that grammar of a language should have its role in the teaching of foreign languages. The dilemma which a teacher can face is: at what point grammar should be introduced in the teaching process, what grammar points should be taught, as well as what method of teaching grammar should be introduced. It all seems to be dependent on the students' age, their knowledge of language, as well as their goal of learning a foreign language.

Which approach to teaching grammar of a foreign language is the most efficient one? One of the most frequently asked, yet unanswered question is if students should focus on the rule before using the structural forms, which is the deductive approach, or use grammatical structures in functional exercises before presentation of a rule, which is referred to as the inductive approach. This paper explores the issue by means of investigating whether the students

4 Grammar-translation method, widely used for teaching Latin and Greek in XVIII and XIX century, used as the most frequent method during the WWII, and present even in today's teaching, though not to a large extent

5 This attitude was present at the beginning of communicative teaching, where the emphasis shifted from the language system as a sole aim of language acquisition to the usage of the system in context. 
prefer the traditional or deductive approach, primarily focusing on form, or the inductive approach, primarily based on a specific language function in correlation with a specific context and meaning.

\title{
LITERATURE REVIEW
}

\author{
WAYS OF GRAMMAR LEARNING (ACQUISITION)
}

The term mother tongue refers to the language that is acquired first and, in pedagogical context, named as the native, base, or source language. A foreign language is a language taught at school as a subject, as well as the one that is not used either as a language of teaching at school or the language of communication in a certain community. In pedagogical context, it is referred to as a foreign, goal or target language. In linguistic literature it can be noticed that different scholars have treated the distinction between the terms "learning" and "acquiring" in numerous ways. American linguist Krashen (1987) insists that those are two completely different processes. According to him, the acquisition is a process of learning a mother tongue which is considered unique by its own nature. Learning in a broader sense can be defined as "acquiring or getting of knowledge of a subject or a skill by study, experience and instruction." (Brown, 1980, p. 7) On the other hand, some linguists claim that there exists no fundamental distinction between the two terms (Stern, 1983: 56). Further in the text, the term grammar acquisition will be used, for the fact that in pedagogical and psycholinguistic literature it is often used in alternation with the term learning.

There are at least two approaches to acquisition of grammar in teaching foreign languages: inductive and deductive. When grammar is taught inductively, a teacher allows students to, on the basis of assumptions, induce and formulate a rule by themselves (Thornbury, 1999: 54-55). Namely, students produce rules indirectly, applying a rule to exercises from a text. The teacher's task is to provide the appropriate context where a certain rule is used, together with the appropriate context for communication. The main advantage of the inductive approach, according to Hinkel and Fotos (2002), is fostering the mental effort and enabling develop- 
ment of students' mental capabilities, analysis and making connection between the segments of speech, thus participating actively in the teaching process. They also assert that the knowledge acquired by unconscious process of identification and acquisition of the presented grammar rules can be stored for a longer period of time and implemented in practice without the conscious questioning of context which can be time-consuming. Naturally, the efficiency of the method is highly dependent on the teacher for it is highly demanding to find examples relevant for the given problem which will lead to the desirable conclusion. Moreover, the method could be time-consuming, wasting precious time that could otherwise be used for the reproduction of the learnt material, especially in the case when, for instance, the students are unable to produce a certain rule.

The second approach is the deductive approach of acquiring grammar rules. According to Thornbury's three basic principles, a teacher provides clear definitions and explanations of a certain grammar point. The next step is to provide examples of sentences where the grammar point is usually used, as a means of presenting the students with the most frequent usage of a rule in a certain context. Then students practice the rule providing their own examples at the end of a lesson (Thornbury, 1999: 54-55). The deductive method is easier to apply than the inductive one, leaving little space for mistakes, provided it is explained in a correct and precise way. The deductive approach encourages students' confidence through numerous examples, at the same time stating clearly what students are expected to learn. In addition, a teacher is not required to prepare much when teaching in this manner. The main task of a teacher is to provide students with comprehensible explanation which could be easily applied to the exercises that follow. However, one of the main disadvantages of the deductive approach is the lack of students' participation in the teaching process, which leads to the lack of creativity and degradation of the thinking process because everything is clear, already given and there is no opportunity for critical thinking. Teacher's inability to present a rule in a clear and unambiguous way, to provide relevant examples and adjust them to the capabilities of the students could be another disadvantage of the approach. In that case, even the simplest rule can seem difficult and confusing to the students. 
In the area of exploring the attitudes of students and teachers towards grammar teaching, the researchers mostly focused on grammar in general, while the analysis of attitudes towards the one or the second method has been less present. Despite the rich theoretical perspectives, when the methods of acquiring grammar rules are concerned, a relatively small number of research has been conducted in order to compare the approaches in question. Previous studies about the efficiency of inductive or deductive approach have yielded different and often contradictory results.

The study conducted by Burgess and Etherington (2002) focuses on 48 teachers of English for Academic Purposes in British university language centers. Namely, the results have shown that the teachers are aware of the role of grammar in language teaching, as well as the issues concerning the way it is introduced in modern language teaching. Although the teachers prefer the inductive way of teaching grammar, they admit that their students feel much confident when they are explicitly presented with grammar rules. Other studies also indicate that there is a mismatch between the attitudes of students and teachers in the area of the ways of grammar teaching (for example Al-Kalbani, 2004; Borg and Burns, 2008).

The majority of empirical researches which aimed at comparing the inductive and deductive approaches conclude that the deductive approach could be a little more efficient (Robinson, 1996; Noris and Ortega, 2000). The variation the results have shown could have been influenced by the variety of research structure, conditions of their performing, as well as by the participants. Ellis (2010) argued that the inductive approach is much more efficient and that grammatical structures thus acquired last longer.

Despite the differences between cognitive psychologists and linguists when it comes to the most efficient way of acquiring a foreign language, many scholars have agreed that elements of formal structures are indeed important in foreign language acquisition (Sherwood, 1988; Long, 1991). Generally speaking, all the previous researches indicate that focus on form along with communication is a more efficient technique than focusing on mere form or mere communication. Thus, on the basis of the abovementioned, it can be concluded that during the teaching process a teacher should take advantage of both approaches in order to achieve favorable results. 


\section{RESEARCH METHODOLOGY}

Accurate and efficient grammar acquisition represents a very significant moment in foreign language acquisition. Therefore, students' preferences, affinities and abilities must be taken into consideration in order to learn a foreign language easier. Our task was to examine which approach the students prefer (inductive or deductive), with the aim of improving the teaching process. Moreover, the hypothesis of this research is that the students prefer the inductive approach of teaching grammar of English language.

\section{RESEARCH INSTRUMENT}

The research instrument represents a short questionnaire administered among students with the aim of determining their attitude concerning the inductive and deductive approaches to English language teaching. Most items of the questionnaire have been adapted from the research conducted by Burges and Etherington (2002), with the exception of certain questions being altered to meet the subject and purpose of the research.

The questionnaire consists of two sections: the first section includes questions which refer to the respondents' gender, the marks achieved in the course English language at the end of the winter semester, the time spent learning English, as well as the experience in language learning (at school and/or outside school). The second section of the questionnaire examines the students' attitudes concerning the inductive and deductive teaching of English grammar. This part is comprised of 15 statements which were evaluated by students according to Likert's five-point scale: 1 = always, 2 = very often, 3 = sometimes, $4=$ rarely, $5=$ never. The purpose of this questionnaire is to examine the students' attitudes towards the inductive and deductive approaches in teaching English grammar through questionnaire items which describe the students' experiences and the results they achieve. The results of the research are shown in percentages in tables.

DATA COLLECTION PROCESS AND RESEARCH LIMITATIONS

Data was collected for a period of approximately four months, including the length of one semester and first final examination in 
January. The questionnaire was conducted among 134 students, who attended the Business English course in the period of the winter semester in the school year of 2014/2015; all students willingly agreed to participate in the research. The instructions were given in written form and there were no options for additional questions and explanations.

There are certain limitations which must be taken into account when interpreting the obtained results. Primarily, the research sample is relatively small, so the research results must be taken with caution and cannot be generalized. Another weakness is the absence of interviews with students, the results of which might have influenced the final conclusions of this research.

\section{RESULTS ANALYSIS AND DISCUSSION}

134 students took part in the research, $46.3 \%$ of whom are male and $53.7 \%$ female. Regarding the age of students, $9.7 \%$ are $19 ; 24.6 \%$ are $20 ; 32.1 \%$ are $21 ; 20.9 \%$ are 22 and $12.7 \%$ are those older than the stated age. All respondents attended an obligatory course of Business English.

Table 1 highlights students' achievement at the end of winter semester by means of their final mark in the course English language, shown in percentages. Namely, the results show that a great percentage of students passed the exam (81.6\%), whereas only $19.4 \%$ students still have not passed the exam. The highest mark (ten) was achieved by $10.4 \%$ students, while $14.9 \%$ students passed the exam with the mark nine. At the end of the semester, $19.4 \%$ students had the mark eight, whereas most students (20.9\%) scored a seven. $14.9 \%$ students passed the course with the mark six.

\begin{tabular}{c|cc}
\hline MARK & NUMBER & PERCENTAGE \\
10 & 22 & $10.4 \%$ \\
9 & 16 & $14.9 \%$ \\
8 & 26 & $19.4 \%$ \\
7 & 28 & $20.9 \%$ \\
\hline
\end{tabular}

TABLE 1: MARKS IN THE COURSE ENGLISH LANGUAGE 


\begin{tabular}{c|cc}
\hline 6 & 20 & $14.9 \%$ \\
5 & 22 & $19.4 \%$ \\
\hline
\end{tabular}

TABLE 1: MARKS IN THE COURSE ENGLISH LANGUAGE

As far as previous knowledge of English is concerned, Table 2 indicates the results which indicate that all respondents have certain knowledge of English. Namely, the results show that the greatest part of students (64.1\%) have learned English more than eight years; $6.0 \%$ students have learned English for the period of 1 to 4 years, while almost a third of the respondents have learned English from 4 to 8 years.

\begin{tabular}{c|cc}
\hline $\begin{array}{c}\text { NuMBER OF YEARS SPENT } \\
\text { IN LEARNING }\end{array}$ & PERCENTAGE \\
0 & 0 & 0 \\
$1-4$ & 8 & 6.0 \\
$4-8$ & 40 & 29.9 \\
$8-$ & 86 & 64.1 \\
\hline \hline
\end{tabular}

TABLE 2: THE PERIOD SPENT IN LEARNING ENGLISH

The question about whether the students learned English exclusively in school was answered affirmatively by most of the respondents (80.6\%), whereas the rest (19.4\%) added that they obtained their knowledge of English in private schools for English language teaching, as well as during private classes, through movies, music, TV series, video games, through the Internet, social networks and during their stays abroad.

The results of the questionnaire indicate that the students, to a greater or lesser extent, have certain prior knowledge of English, which implies that they obtained this knowledge through certain teaching methods. Therefore, the students' answers will help us make conclusions whether they prefer to learn English grammar through inductive or deductive teaching approaches. The students' prior knowledge involves both learning the language in school and outside school. 


\section{STUDENTS' ATTITUDES TOWARDS INDUCTIVE AND DEDUCTIVE TEACHING} OF ENGLISH GRAMMAR - RESULTS AND ANALYSIS OF THE RESULTS

The task of the research was to determine which of the two mentioned approaches the students prefer. Table 3 depicts an overview of the questionnaire results which was answered by 134 students at the Business School of Applied Studies in Blace.

\begin{tabular}{|c|c|c|c|c|c|}
\hline STATEMENT & 1 & 2 & 3 & 4 & 5 \\
\hline $\begin{array}{l}\text { 1. Students can acquire grammar if they are } \\
\text { exposed to the target language, without prior } \\
\text { explanation of the rules. }\end{array}$ & $23.2 \%$ & $9.0 \%$ & $21.6 \%$ & $13.4 \%$ & $32.8 \%$ \\
\hline $\begin{array}{l}\text { 2. Formal instructions help students to } \\
\text { generate grammatically correct } \\
\text { constructions. }\end{array}$ & $33.6 \%$ & $32.1 \%$ & $29.9 \%$ & $2.2 \%$ & $2.2 \%$ \\
\hline $\begin{array}{l}\text { 3. Students prefer when the teacher presents } \\
\text { and explains the rules of grammatical } \\
\text { structures. }\end{array}$ & $65.7 \%$ & $17.9 \%$ & $13.4 \%$ & $0.8 \%$ & $2.2 \%$ \\
\hline $\begin{array}{l}\text { 4. Grammar acquisition in students does not } \\
\text { involve conscious knowledge of the } \\
\text { grammatical structures and the rules for } \\
\text { their functioning. }\end{array}$ & $29.1 \%$ & $14.2 \%$ & $38.8 \%$ & $4.5 \%$ & $13.4 \%$ \\
\hline $\begin{array}{l}\text { 5. Students need conscious knowledge of } \\
\text { grammar in order to improve the knowledge } \\
\text { of language. }\end{array}$ & $69.4 \%$ & $13.7 \%$ & $7.5 \%$ & $4.5 \%$ & $2.9 \%$ \\
\hline $\begin{array}{l}\text { 6. Students actively participate in making } \\
\text { grammatical rules. }\end{array}$ & $15.7 \%$ & $12.7 \%$ & $29.8 \%$ & $11.2 \%$ & $30.6 \%$ \\
\hline $\begin{array}{l}\text { 7. The practice of grammatical structures } \\
\text { must always be performed within context, } \\
\text { never through isolated examples.. }\end{array}$ & $38.8 \%$ & $4.5 \%$ & $44.8 \%$ & $10.4 \%$ & $1.5 \%$ \\
\hline $\begin{array}{l}\text { 8. Explicit explanation of the grammatical } \\
\text { rules is useful for students. }\end{array}$ & $67.2 \%$ & $4.5 \%$ & $17.9 \%$ & $7.5 \%$ & $2.9 \%$ \\
\hline $\begin{array}{l}\text { 9. Students must be acquainted with the form } \\
\text { and function of a certain grammatical struc- } \\
\text { ture before they use it in context. }\end{array}$ & $\begin{array}{l}76.1 \\
\%\end{array}$ & $\begin{array}{l}6.0 \\
\%\end{array}$ & $13.4 \%$ & $4.5 \%$ & $0 \%$ \\
\hline
\end{tabular}

TABLE 3: QUeSTIONNAIRE RESULTS ABOUT THE INDUCTIVE AND DEDUCTIVE APPROACHES OF TEACHING ENGLISH GRAMMAR 


\begin{tabular}{l|ccccc}
\hline $\begin{array}{l}\text { 10. Students prefer to find the connections } \\
\text { between grammatical structures and the } \\
\text { rules for their use on their own. }\end{array}$ & $13.4 \%$ & $15.0 \%$ & $28.4 \%$ & 10.4 & $32.8 \%$ \\
$\begin{array}{l}\text { 11. Teachers should correct only those } \\
\text { mistakes which complicate communication. }\end{array}$ & $51.5 \%$ & $3.7 \%$ & $29.9 \%$ & $11.2 \%$ & $3.7 \%$ \\
$\begin{array}{l}\text { 12. Comparing and contrasting certain } \\
\text { grammatical structures is useful in mastering } \\
\text { grammar. }\end{array}$ & $43.3 \%$ & $25.4 \%$ & $23.9 \%$ & $3.7 \%$ & $3.7 \%$ \\
$\begin{array}{l}\text { 13. The best way for mastering grammar is to } \\
\text { participate in activities which refer to } \\
\text { everyday situations. }\end{array}$ & $73.9 \%$ & $8.4 \%$ & $13.5 \%$ & $3.7 \%$ & $0.7 \%$ \\
$\begin{array}{l}\text { 14. When grammar is taught separately from } \\
\text { other language components, students are not } \\
\text { able to apply such knowledge in everyday } \\
\text { communication. }\end{array}$ & $37.2 \%$ & $10.4 \%$ & $40.4 \%$ & 10.4 & $1.6 \%$ \\
$\begin{array}{l}\text { 15. Students can improve the use of } \\
\text { grammatical structures through constant } \\
\text { practice. }\end{array}$ & $77.6 \%$ & $7.5 \%$ & $10.4 \%$ & $4.5 \%$ & $0 \%$ \\
\hline
\end{tabular}

TABLE 3: QUESTIONNAIRE RESULTS ABOUT THE INDUCTIVE AND DEDUCTIVE APPROACHES OF TEACHING ENGLISH GRAMMAR

As it can be seen in Table 3, when statements ${ }^{6}$ about the inductive approach are in question, $32.8 \%$ of the respondents acknowledged that it is not possible ( $13.4 \%$ says it is rarely possible) to acquire grammar without prior explanation of the rules (statement 1.), whereas the fourth statement, which claims that grammar acquisition does not only involve conscious knowledge of the grammatical rules, has shown very similar results like the previously mentioned statement.

Another statement which concerns the inductive approach of grammar teaching (statement 6.) shows that almost half of the respondents admitted that the students do not take an active part in the formation of grammatical rules. In addition, a large number of respondents stated that they do not prefer finding connections between grammatical structures and rules on their own (statement $10 ; 43.3 \%$ of which $32.8 \%$ never and $10.4 \%$ rarely do so). More than a

6 There are 15 statements in the questionnaire which are represented in the Table. The statements which refer to the deductive approach in teaching English grammar are: 2, 3, 5, 8, 9, 12 and 15 , whereas the ones which refer to the inductive approach are: $1,4,6,7,10,11,13$, and 14 . 
half of the respondents (51.5\% always and 3.7\% very often) think that teachers should correct only those mistakes that in some way interfere with communication (statement 11.). As far as statement 13 is concerned, most students (73.9\% always and $8.4 \%$ very often) indicate that it is very important to participate in activities which refer to situations from everyday life.

As for the statements which favour the deductive approach, students mainly agree that formal instruction of English grammar, as well as explanation of grammatical rules, helps them in using the language correctly (statements 2 . and 3.). There are in particular a great number of those who agree that the teacher should explain the rules for grammatical structures $(65.7 \%$ always and $17.9 \%$ very often) and those who require conscious knowledge of grammar (69.4\% always and $13.7 \%$ very often). A large number of students (67.2\% always and $4.5 \%$ very often) consider explicit explanations useful and they want to be familiar with the form and the function before using it in a context ( $76.1 \%$ and $6.0 \%$ very often). Finally, $77.6 \%$ respondents feel confident that they can improve the use of grammatical structures through constant practice (statement 15.).

However, if we combine the results obtained for each statement which favours the inductive or deductive approach for teaching grammar, we obtain a graph (Figure 1) where the students' preference of the deductive approach for teaching English grammar is clearly visible.

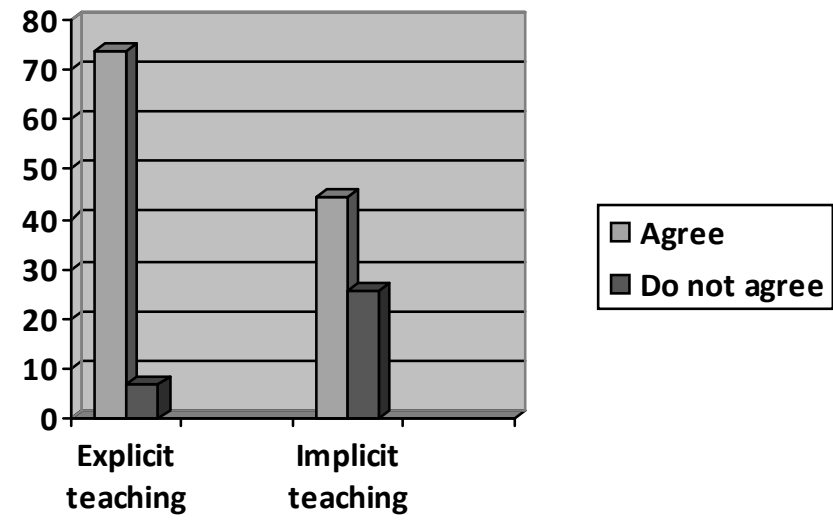

FigURE 1: STUDENTS' ATTITUDES TOWARDS EXPLICIT/IMPLICIT LANGUAGE TEACHING 
Namely, the obtained results indicate that over $70 \%$ of students prefer explicit teaching of the English language, while more than $40 \%$ consider implicit language teaching also important for mastering English grammar. It can be concluded that most respondents believe that explaining rules, in other words, formal instruction, as well as the knowledge of forms and functions of grammatical structures and constant practice plays a very important role in learning English grammar. Nevertheless, we must not disregard the fact that the students recognize the significance of the inductive approach, since slightly less than half of the students consider that learning grammar through finding connections between the grammatical structures and the rules for their use on their own can be useful as well.

The results which were particularly interesting were obtained during the analysis of students' attitudes towards learning grammar through isolated examples in comparison to examples in context. As it can be seen in the graph in Figure 2, the students find both approaches for practicing grammar to be of almost equal importance.

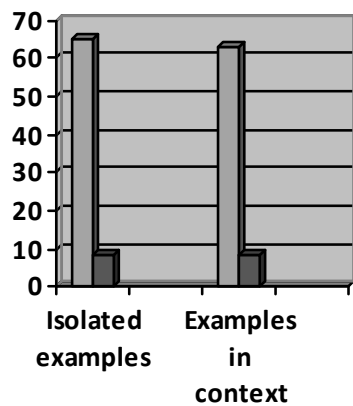

$\square$ Agree

$\square$ Do not agree

FIGURE 2: STUDENTS' ATTITUDES TOWARDS GRAMMAR LEARNING THROUGH ISOLATED EXAMPLES AND EXAMPLES IN A CONTEXT.

Such results show that students need variety; that they must not be limited to only one approach, but they should rather be offered a possibility of choice through a combination of different methods and approaches to language teaching. Another possible explanation could be that students, as native speakers of Serbian, were not (or were rarely) exposed to the target language outside the class- 
room; therefore, the teacher is expected to pay special attention to the language forms and structures themselves, and then provide a specific context in which these structures can be applied efficiently.

Based on everything that was mentioned, it can be concluded that the students who participated in this research favour the deductive approach to teaching English grammar. They have encountered both the inductive and the deductive approaches in teaching English but, contrary to the expectations of our research, they decided that the deductive approach in learning English grammar helps them more in mastering grammatical structures. Although it has been generally accepted that students in traditional teaching of grammar have a passive role - they are excluded from discussion and their opinions are not asked for, the respondents still chose this approach to teaching. The reason for such a choice might be due to their prior experience in learning English in elementary and secondary school. Namely, they are used to the traditional approach in teaching and it is easier for them to pursue familiar and safe methods. Although the results obtained are opposite to what was assumed by the authors, in such a situation it would be desirable to establish an atmosphere in which students are active participants and not only passive observers in the process of learning a foreign language. Therefore, greater attention should be paid to the learning process and to individual characteristics of the students, rather than to teachers and the teaching itself.

\section{CONCLUSION}

The aim of this study was to determine students' attitudes towards deductive and inductive approaches that are used in teaching English grammar. With the aim of obtaining the desired results, 134 students from the Business School of Applied Studies in Blace were included in this study. After a detailed analysis and discussion of the results for the conducted survey, it can be concluded that the main assumption that students prefer the inductive approach in teaching English grammar is not accurate for this research. Namely, the students have stated that they favour the traditional approach in teaching grammar, where the teacher offers formal explanations of grammatical rules and then those rules are practiced by students 
through numerous examples. This does not mean that there is not a great number of those who chose the inductive approach for teaching grammar. The reason for such results of the conducted survey can be found in elementary and secondary education of the students. The results indicate that the students are used to learning English grammar by being exposed to deductive teaching. They feel insecure when they have to make conclusions on their own, when the rules are not explained to them explicitly. However, it is significant to note that the students still recognize the positive aspects of the inductive approach. Most importantly, students are willing to take part in activities which refer to everyday situations and not to view English grammar through isolated examples, outside the context. If grammar is taught using isolated examples, the students will not be able to apply such knowledge in everyday communication. Finally, it can be concluded that combining these two approaches is what suits the students best. Therefore, the students acknowledged that certain parts should be presented deductively, such as grammatical rules. Furthermore, they find practicing grammar through numerous examples very useful. Inductive approach to grammar teaching is accepted when communication is concerned, and communication is possible only when it is based on everyday situations from our lives. English grammar teaching can be improved by encouraging students to think and make conclusions, as well as through active acquisition of English grammar. Perceptions of the Role of Grammar Instruction in EFL Teaching and Learning Unpublished Thesis. Sultan Qaboos University.

Borg, S., and Burns, A. (2008). Integrating grammar in adult TESOL classrooms. Applied Linguistics, 30(3), 355-388.

Brown, D. (1980). Principles of Language Learning and Teaching, Englewood Cliffs: Prentice Hall Inc.

Burgess, J. and Etherington, S. (2002). „Focus on Grammatical Form: Explicit or Implicit?" System 30: 433-458.

Chastain, K. (1969). "The Audio-Lingual Habit Theory Versus the Cognitive Code-Learning Theory: Some Theoretical Considerations." International Review of Applied Linguistics, 7, 97-106.

Dinneen, F. (1995). General linguistics, Washington, D.C.: Georgetown University Press. 
Ellis, R. (2010). Does Explicit Grammar Instruction Work? Ninjal Project Review. 2, 3-22

Fosnot, T. (1989). Enquiring teachers, enquiring learners: A constructivist approach forTeaching, New York: Teachers College Press.

Gardner, H. (1983). Frames of mind: The theory of multiple inteligencies, New York: Basic Books.

Herron, C. \& Tomasello, M. (1992). Acquiring grammatical structures by guided Induction, Oxford: Heineman.

Hinkel, E. and Fotos, S. (2002) New Perspectives on Grammar Teaching in Second Language Classrooms. New Jersey: Lawrence Erlbaum Associates, Inc

Krashen, D. (1987). Principles and practices in second language acquisition, New York: Prentice-Hall.

Long, M.H. (1991). „Focus on form: a design feature in language teaching approachology." In: de Bot, K., Ginsberg, R., Kramsch, C. (Eds.), Foreign Language Research in Cross-Cultural Perspective. John Benjamins, Amsterdam, pp.39-52.

Norris, J. M., Ortega, L. (2000). Effectiveness of L2 instruction: A research synthesis and quantitative meta analysis. Language learning, 50(3), 417-528. Robinson, P. (1996). „Learning Simple and Complex Second Language Rules Under Implicit, Incidental, Rule-search, and Instructed Conditions." Studies in Second Language Acquisition, 18 (1): 27-67.

Sherwood, JN. (1988). The cT Language. Stipes, Champaign, IL.

Stern, H. (1983). Fundamental concepts of language teaching, London: Oxford University Press.

Thornbury, S. (1999). How to Teach Grammar, England: Pearson Education Limited. 
ИВАНА Д. НЕШИЋ

ВИСОКА ПОСЛОВНА ШКОЛА СТРУКОВНИХ СТУДИЈА

БЛАЦЕ

КИМЕТА Ћ. ХАМИДОВИТ

ДРЖАВНИ УНИВЕРЗИТЕТ У НОВОМ ПАЗАРУ

ФИЛОЛОШКИ ФАКУЛТЕТ

РЕЗИМЕ

НАСТАВА ГРАМАТИКЕ ЕНГЛЕСКОГ ЈЕЗИКА: ЕФИКАСНОСТ ИНДУКТИВНЕ И ДЕДУКТИВНЕ МЕТОДЕ - ПЕРЦЕПЦИЈЕ СТУДЕНАТА

Када је у питању настава граматике страног језика, увек се поста-вља питање да ли студентима експлицитно објаснити правила, а затим та правила применити на бројним примерима (дедуктивна метода) или је учење граматике ефикасније када су студенти изложени циљном језику, другим речима, када студенти сами долазе до граматичких правила на основу употребе језика у свакодневним ситуацијама.

На почетку рада дат је опис индуктивне и дедуктивне методе наставе граматике страног језика. Наиме, када се граматика предаје индуктивно наставник прво износи контекст у коме се нека граматичка јединица налази, док студенти имају задатак да уоче и сами дођу до одређеног правила. Када је у питању дедуктивна метода, наставник најпре експлицитно објашњава студентима одређено граматичко правило, а затим наводи примере којима се то правило доказује.

Циљ истраживања био је да се утврди коју методу студенти, који су ठили изложени и индуктивној и дедуктивној методи наставе граматике енглеског језика, преферирају. Хипотеза истраживања је да студенти преферирају индуктивну методу и да њеном употребом долази до побољшања наставе граматике енглеског језика. У ту сврху 134 студента Високе пословне школе струковних студија у Блацу попунила су упитник од 15 питања која се тичу ставова према индуктивној односно дедуктивној методи наставе граматика. Анализа резултата показала је да више од 70\% студената преферира дедуктивну методу наставе граматике енглеског језика, док се око 40\% определило за индуктивну методу. Иако се већина студената определила за екплицитно објашњавање граматичких правила, важно је напоменути да су студенти вољни да учествују у активностима које се односе на свакодневне ситуације, односно, желе да научене граматичке форме увежठавају на примерима из свакодневног 
живота. Ово нас води до закључка да се најбољи резултати постижу комбиновањем ове две методе наставе страног језика. Даље следи да су формалне инструкције исто толико важне као и охрабривање студената на размишљање и активно учествовање у процесу наставе и учења који се ठазира на примерима из одређеног контекста.

КључнЕ РЕчи: настава граматике енглеског језика, индуктивна метода, дедуктивна метода, перцепција студената. 